\title{
THE ROLE OF ULTRASOUND ELASTOGRAPHY IN THE DIAGNOSIS OF PATHOLOGIC CONDITIONS OFTESTICLES AND SCROTUM
}

\author{
Miroslav Muršić ${ }^{1}$, Ivica Sjekavica ${ }^{1,2}$, Marko Šimunović ${ }^{1}$ and Davor Ježek ${ }^{2,3}$ \\ ${ }^{1}$ Department of Diagnostic and Interventional Radiology, Zagreb University Hospital Centre, Zagreb, Croatia; \\ ${ }^{2}$ University of Zagreb, School of Medicine, Zagreb, Croatia; \\ ${ }^{3}$ Department of Transfusion Medicine and Transplantation Biology, \\ Zagreb University Hospital Centre, Zagreb, Croatia
}

\begin{abstract}
SUMMARY - Several years ago, elastography emerged as a potentially very useful ultrasound technique that is currently used in diagnostic workup of the breast, liver and some other organ systems, whereas for other ones it is still mainly in the phase of research. The aim of the study was to compare elasticity index (EI) of testicles using strain elastography in healthy subjects and those with pathologic changes of testicles/scrotum. A total of 117 patients were included in the study. Measurements were performed on a Logiq E9 ultrasound system using strain elastography. In healthy subjects, the mean EI value was $1.34 \pm 0.35$ for right testis and $1.49 \pm 0.47$ for left testis. Increased mean EI values were found in the following six conditions: patients with varicocele, infertile patients, solitary testis after orchidectomy of the other testicle because of tumor, patients with testicular tumors, patients after orchidopexy of undescended testicle, and patients with congenitally smaller testicle. There is a paucity of literature data on the use of elastography in testes, as well as on normal elastography values in testicular tissue. Strain elastography was demonstrated to be a valuable method to acquire additional information in patients with pathologic changes in testicles/scrotum. These data provide reference values for further research in a larger sample of subjects.
\end{abstract}

Key words: Ultrasound elastography; Testis; Scrotum; Varicocele; Infertility; Testicular neoplasm

\section{Introduction}

Despite swift radiologic advancement in the fields of computerized tomography and magnetic resonance imaging with impressive technical possibilities, ultrasound examination in B-mode with the use of color Doppler remains the most important imaging method in diagnosing pathology of the scrotum and testicles ${ }^{1,2}$. Over years, technological advancement of technical characteristics of ultrasonic probes, hardware and image postprocessing software, together with Doppler

Correspondence to: Prof. Ivica Sjekavica, $M D, P h D$, Department of Diagnostic and Interventional Radiology, Zagreb University Hospital Centre, Kišpatićeva 12, HR-10000 Zagreb, Croatia E-mail: ivica.sjekavica@kbc-zagreb.hr

Received June 1, 2020, accepted December 6, 2020 has significantly improved diagnosis of scrotal pathology. Indications for ultrasound examination of testicles and scrotum are numerous, most common of which are suspected scrotal mass, scrotal pain, trauma, cryptorchidism, newly discovered varicocele, infertility, detection of occult primary tumors, and testicular infiltration by lymphoma or leukemia.

Very useful techniques have emerged, such as contrast enhanced ultrasound (CEUS) and elastography, which are already in common practice for some organs, but still in the phase of research and evaluation for other organs $\mathrm{s}^{2,3}$. In recent years, all new ultrasound machines from different manufacturers have been implemented with elastography module, which is ever more used in daily routine ${ }^{4}$. Elastography is a noninvasive method used to evaluate the degree of elasticity or hardness of different organs, tissues and lesions 5 . 
Today, two elastography types coexist on the market, i.e. shear wave and strain elastography ${ }^{4,5}$. Shear wave is a quantitative method based on the principle of transmitting mechanical waves from the ultrasound machine in the tissue. Strain elastography is a qualitative or semi-quantitative method based on measuring spatial distribution of elasticity of tissue, apropos its macrostructure in the area of interest by measuring the degree of tissue deformation (elongation).

Hard tissue deforms less than the soft one, which makes it possible to assess different levels of tissue strain and its scaling on the chromatic scale. Elastography uses two measures, i.e. E-index and E-ratio. Eindex is a numerical value of the elasticity in the area of interest; it depends solely on the degree of tissue hardness and it is not affected by user settings. E-ratio is the ratio between two E-indexes. Today, elastography is being used in the diagnosis of breast cancer, thyroid cancer, prostate cancer, in hepatology, lymphatic nodules, gynecologic conditions, and as an additional method in biopsy ${ }^{1,4,6-8}$. A big advantage of this method is that it can be used routinely during conventional ultrasound examination.

In our study, we used strain elastography to determine the value of testicular elasticity in patients with pathologic changes in the testicles or scrotum and in patients with infertility diagnosis, most of which had no morphological abnormalities of the testicles. The results obtained were compared with those in healthy subjects without morphological or functional disorders of the testicles or scrotum.

Our aim was to explore the possibilities of ultrasound elastography and to determine whether there are differences between healthy subjects and patients with pathologic changes in the testicles and scrotum in order to try to increase the specificity and sensitivity of ultrasound examination and to obtain additional information that is not based solely on morphology, but also on tissue elasticity, which could potentially be very useful in the differential diagnosis of multiple pathologic conditions of testes and scrotum.

\section{Patients and Methods}

During the period from November 2015 to September 2017, 117 patients were examined using elastography software and elastography measurements were performed at the Department of Radiology, $\mathrm{Za}^{-}$ greb University Hospital Centre as part of regular and Doppler ultrasound examination of testicles. All measurements in this study were made on a Logiq E9 ultrasonic machine using its strain elastography software. After conventional ultrasound examination in $\mathrm{B}$ mode and color Doppler examination, elastography measurements were performed. The entire examination was performed in a secluded room without the possibility of interruption by a third party. The ultrasound gel was preheated using the built-in heaters and was used in sufficient quantity. The contents of the scrotum were fixed by the patient's hand holding the penis against the front abdominal wall. The examination was performed using a high frequency linear probe (ML6-15-D). The testicles were examined in longitudinal and transverse plane. Afterwards, Doppler examination was performed using color Doppler and spectral analysis. Informed written consent was obtained and all studies were performed according to the Declaration of Helsinki, and the procedures were approved by the local ethics committee.

First, we measured testicular size and volume, we noted any focal lesions of testes and evaluated testicular vascularization. After completing the examination of testicles, we examined other scrotal structures. Epididymis was analyzed, as well as the presence of other possible pathology, such as hydrocele and varicocele. Elastography examination was performed by applying continuous slight manual compression perpendicular to the testicle tissue. By comparing ultrasound signals before and after compression, elastography software calculated tissue strain along each scanned line.

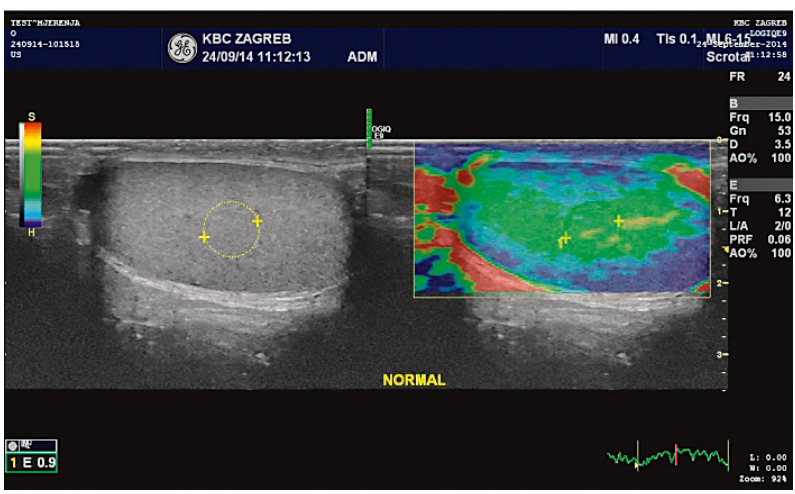

Fig. 1. A healthy subject without pathologic changes in the scrotum (EI 0.9): parallel ultrasound display (left panel) and elastography display (right panel) in real time. 


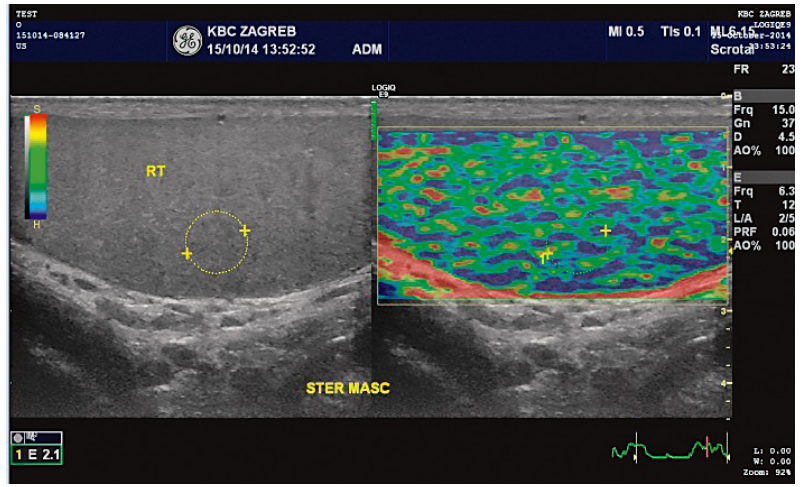

Fig. 2. Patient with diagnosis of infertility, with no abnormal ultrasound findings but with elevated EI value of 2.1.

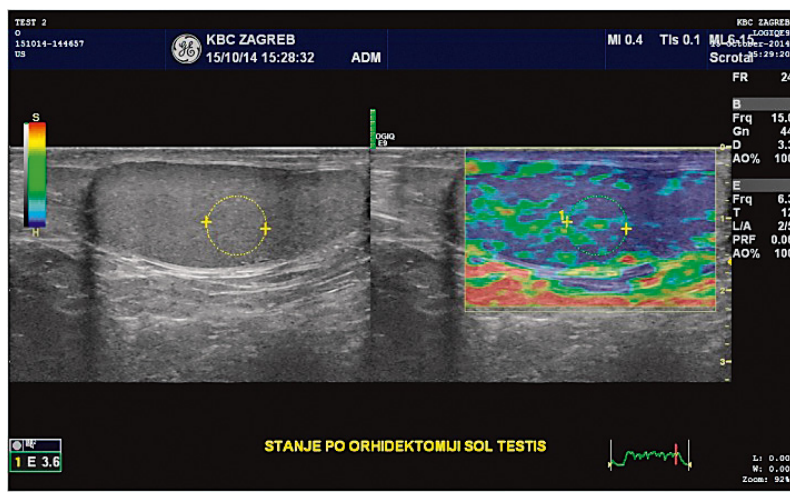

Fig. 3. Patient with solitary testicle after orchidectomy of the other testicle, with no abnormal ultrasound findings but with elevated EI value of 3.6.

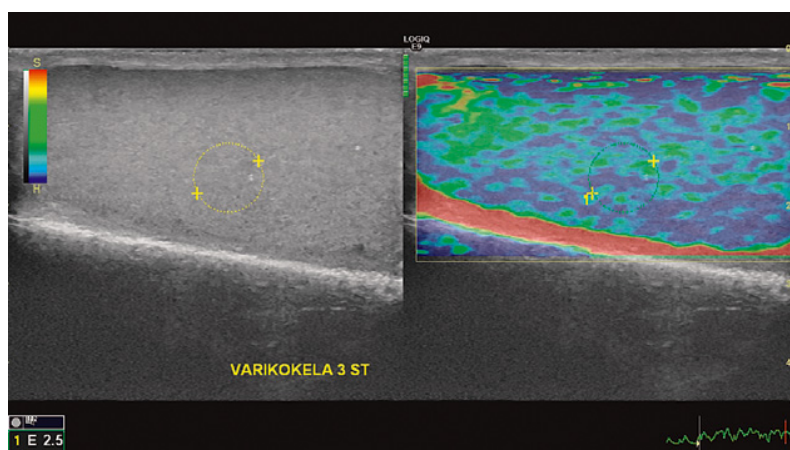

Fig. 4. Patient with left-sided grade 3 varicocele; left testicle with measured EI value of 2.5 .

Measurements were performed in a manually selected region of interest (ROI), chosen as to include the largest possible testicular area or center of the testicle, and in focal lesions ROI was adjusted to the lesion.

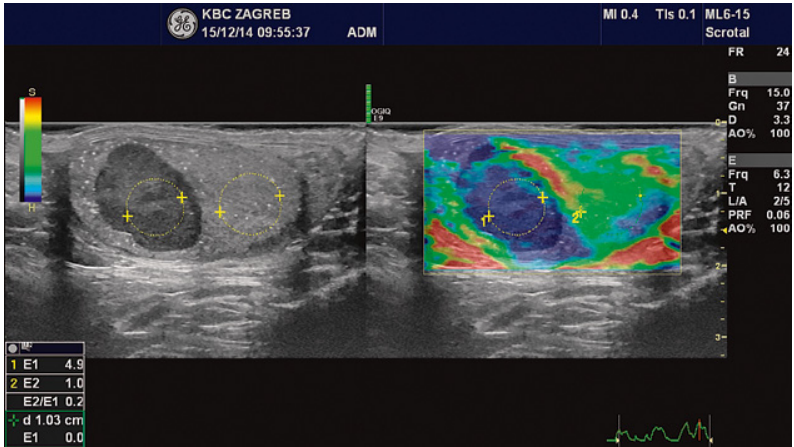

Fig. 5. Patient with testicular tumor: EI value was 4.9 in tumor lesion and 1.0 in the rest of testicular parenchyma.

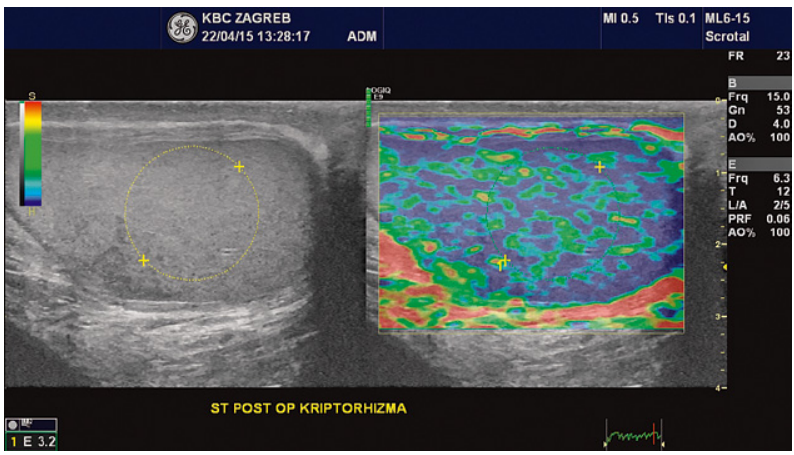

Fig. 6. Patient after orchidopexy of undescended testicle, with no abnormal ultrasound findings but elevated EI value of 3.2.

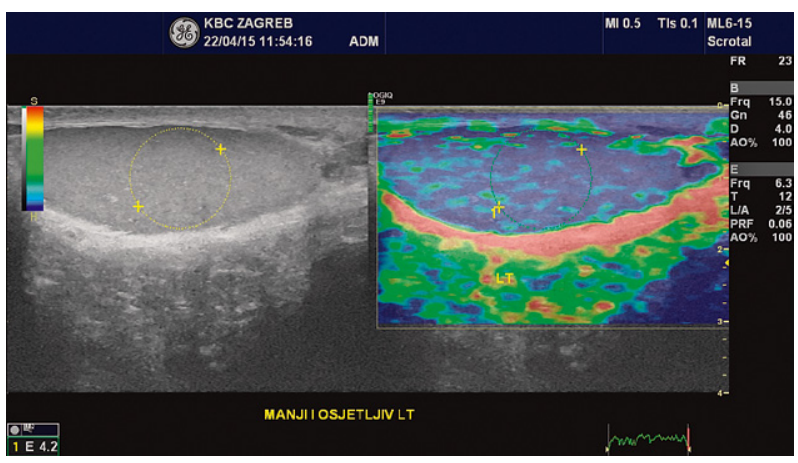

Fig. 7. Patient with congenitally smaller testicle, with no abnormal ultrasound findings but elevated EI value of 4.2.

Several measurements were made per patient and only those performed with optimal pressure with the probe, which were color coded in green color on the separate color coded pressure scale and are considered highly accurate by the ultrasound machine manufacturer, were taken in consideration in our study. 


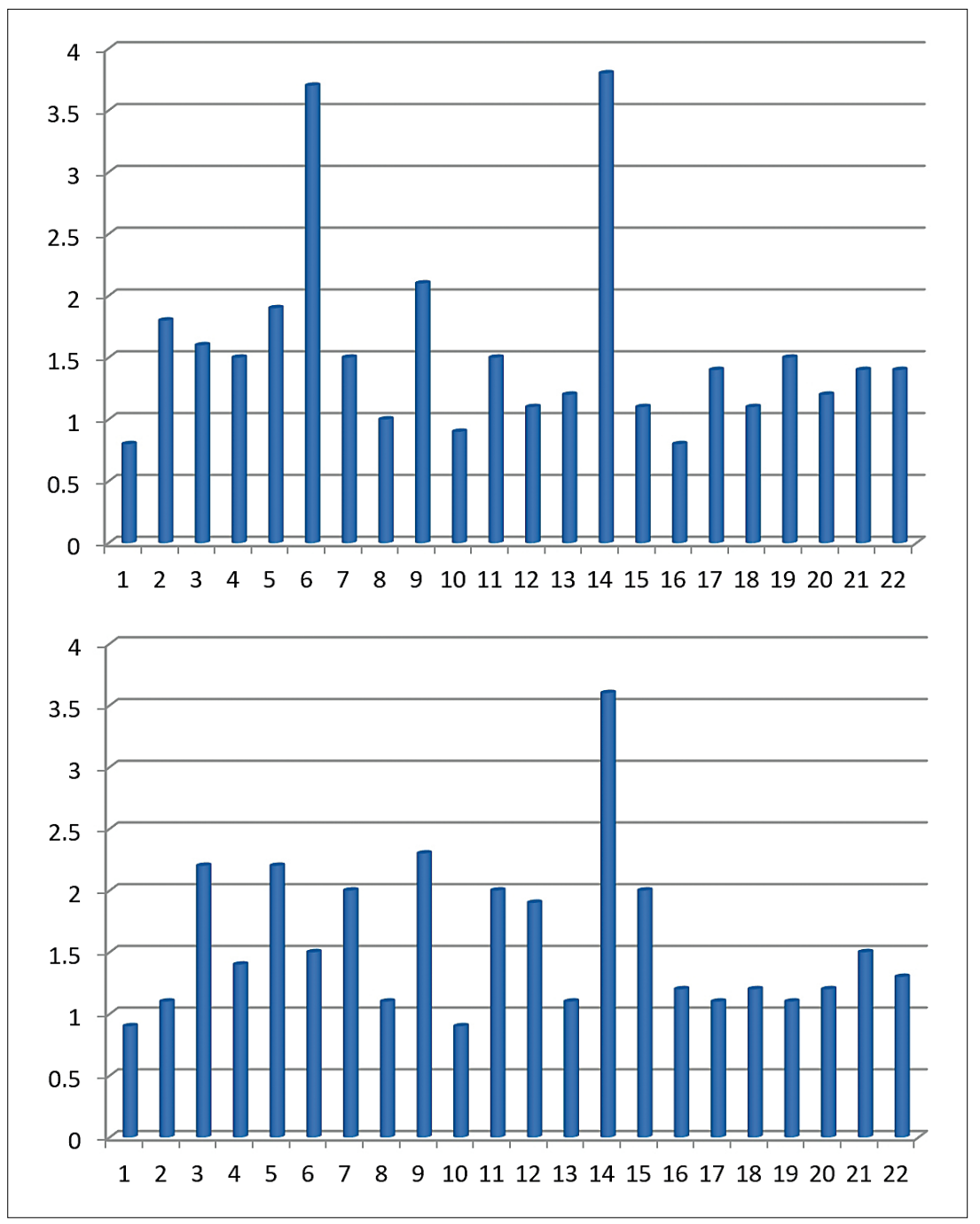

Fig. 8. Healthy subjects, right and left testicle: measured elasticity index values.

Calculated elastography values were scaled on a numeric scale ranging from 0 to 6 , depending on the degree of tissue stiffness, and on a color scale where red color indicated the softest tissue and blue color the stiffest tissue. The attached images (Figs. 1-7) of a normal subject and of patients with pathologic conditions of testicles and scrotum show the ultrasound screen that is divided into two parts; the left half of the screen is a conventional ultrasound display and the right half shows elastography display of the same area in real time.

\section{Results}

We used one sample t-test to compare the means of measured values of elasticity index (EI), to deter- mine whether there was a statistically significant difference in the mean values among different pathologic conditions.

The mean EI value in healthy subjects was $1.34 \pm$ 0.35 for the right testicle and $1.49 \pm 0.47$ for the left testicle. Increased mean EI values were found in the following six conditions: varicocele with a mean EI of $2.14 \pm 0.89$ in 20 patients; infertility with a mean EI value of $1.92 \pm 0.71$ in 18 patients; solitary testis after orchidectomy of the other testicle because of tumor with a mean EI value of $2.35 \pm 1.03$ in 25 patients; patients with testicular tumors with a mean EI value of $3.80 \pm 0.70$ in 6 patients; patients after orchidopexy of undescended testicle with a mean EI value of $2.67 \pm 0.41$ in 3 patients; and patients with congenitally smaller 


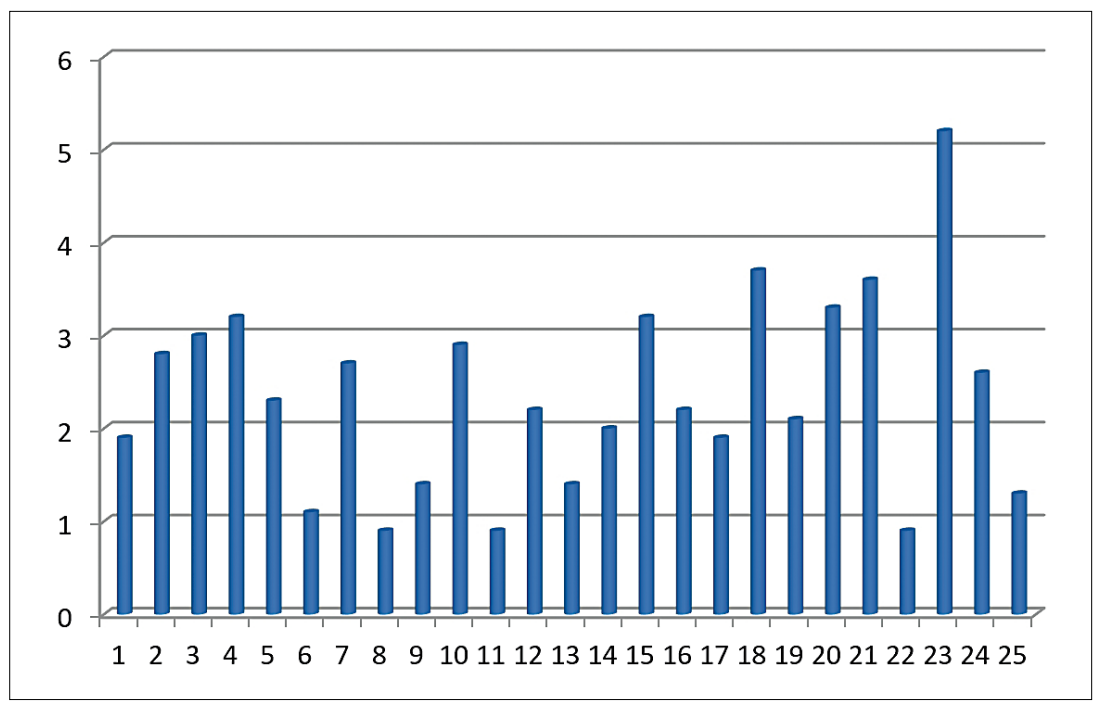

Fig. 9. Patients with solitary testicle after orchidectomy of the other testicle: measured elasticity index values.

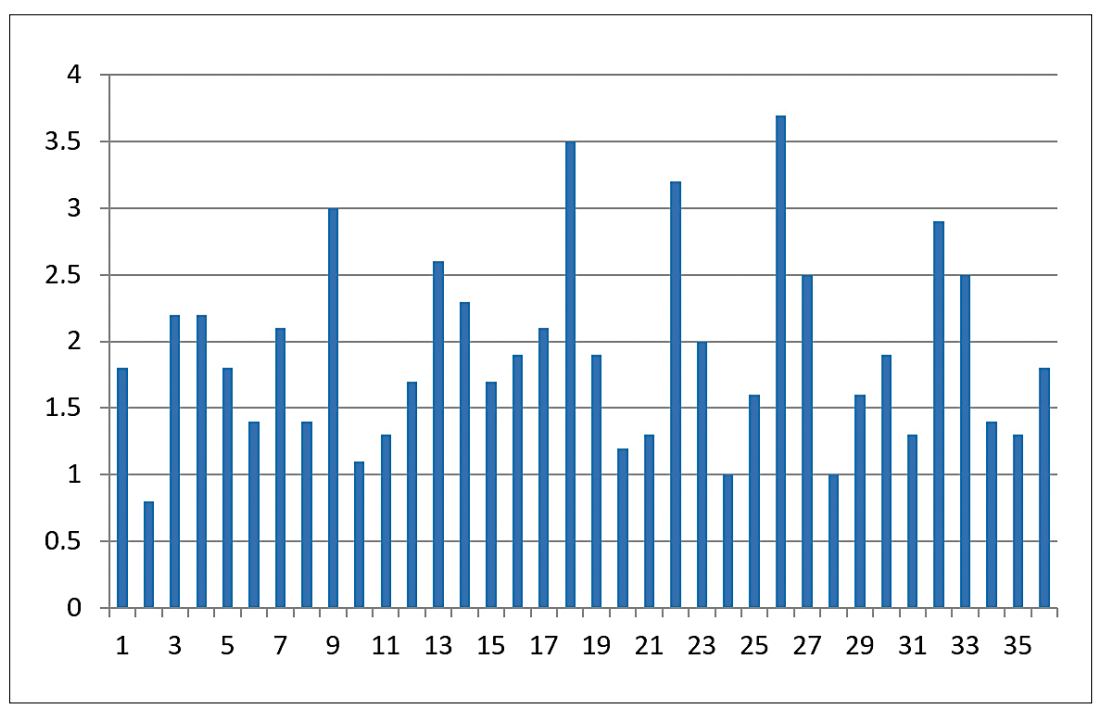

Fig. 10. Patients diagnosed with infertility: measured elasticity index values.

testicle with a mean EI value of $2.70 \pm 0.91$ in 5 patients (Table 1). All the measured values are shown in the corresponding graphs (Figs. 8-14).

By comparing the mean EI values between healthy subjects and patients with pathologic conditions of testes, we found a statistically significant difference between the mean EI value of healthy patients and those with the diagnosis of infertility $(\mathrm{p}=0.006)$, varicocele $(\mathrm{p}=0.013)$, solitary testicle after orchidectomy of the other testicle $(p=0.001)$ and testicular tumors $(p=0.001)$. There were no statistically significant differ- ences between the mean EI values of healthy subjects and patients after orchidopexy of undescended testicle and patients with congenitally smaller testicle, which was, in all likelihood, a result of insufficiently large patient sample (Table 2).

\section{Discussion}

Previous research on elastography has been primarily focused on other organs such as breast, thyroid gland, liver, prostate, and musculoskeletal system. Bal- 


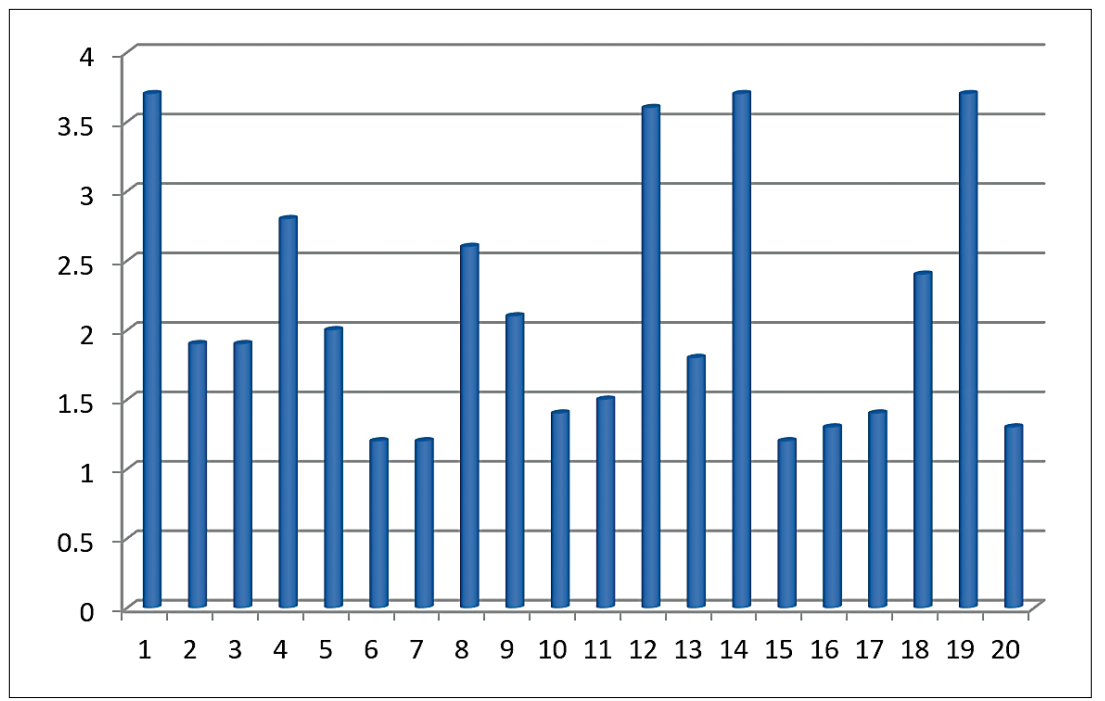

Fig. 11. Patients with varicocele: measured elasticity index values.

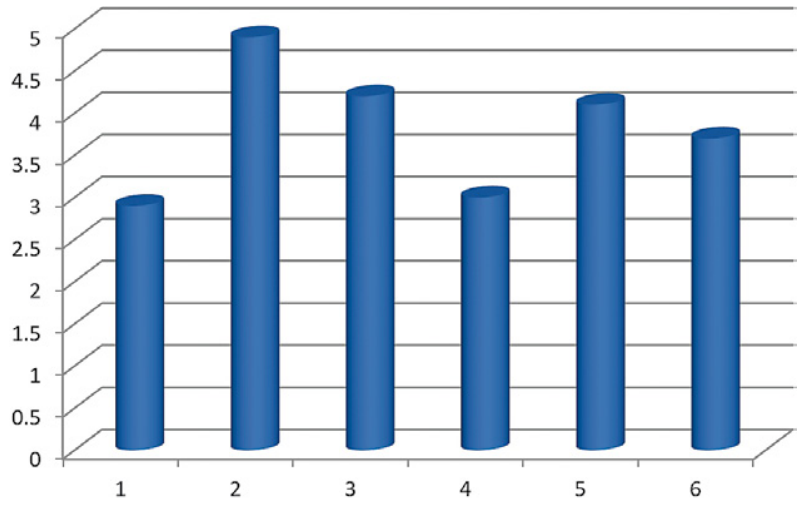

Fig. 12. Patients with testicular tumor: measured elasticity index values.

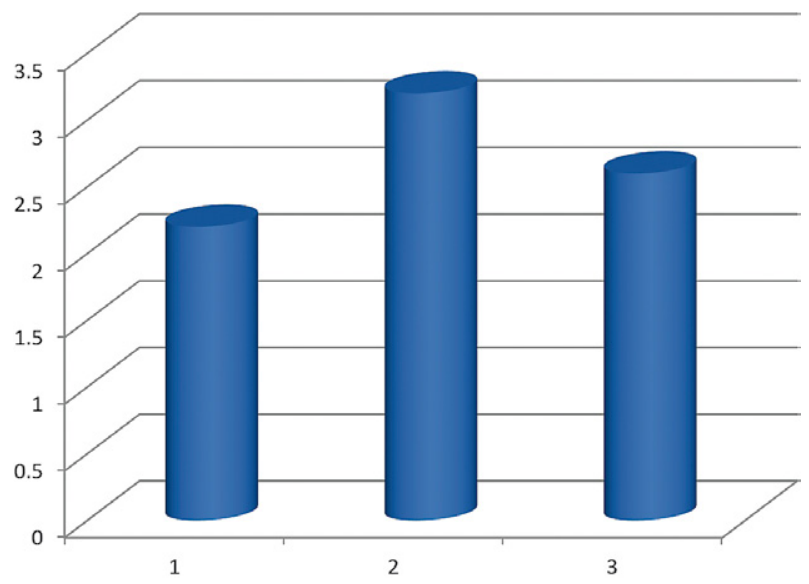

Fig. 13. Patient after orchidopexy of undescended testicle: measured elasticity index values.

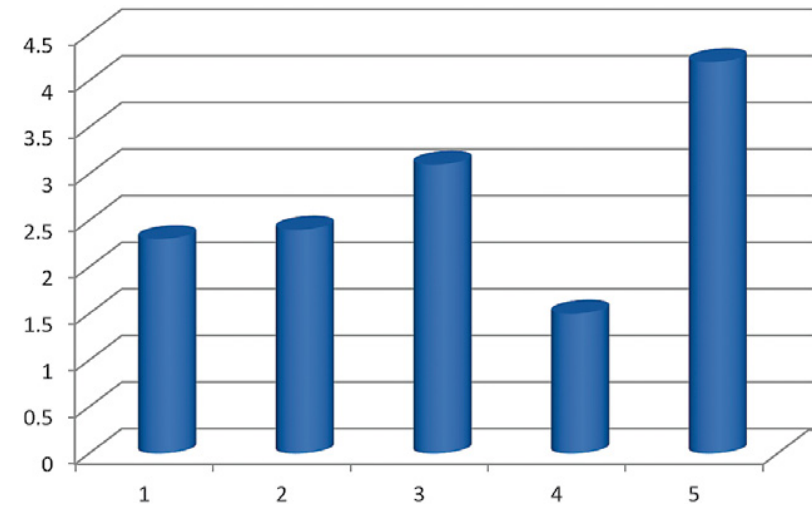

Fig. 14. Patients with congenitally smaller testicle: measured elasticity index values.

leyguier et al. in their research have concluded that ultrasound elastography is a useful complementary tool for undetermined breast lesions categorized as Breast Imaging Reporting and Data System (BI-RADS) 4a or BI-RADS 3, or for cystic lesions ${ }^{9}$. Liu et al. have shown that elastography could be used as a good identification tool for differentiating benign and malignant breast lesions ${ }^{10}$. Monpeyssen et al. conclude that thyroid gland elastography increases the positive predictive value of ultrasound examination and helps in the characterization of thyroid cancer ${ }^{11}$, while Cantisani et al. find that elastography is a valuable tool that has the potential to reduce the number of unnecessary fineneedle aspiration cytology as a complementary ultrasound examination method ${ }^{12}$. Ferraioli et al. find liver 
elastography an effective adjunctive tool for quantifying liver fibrosis ${ }^{13}$. Boehm et al. demonstrated that shear wave elastography allowed discrimination of malignant and benign prostate tissue based on differences in elasticity ${ }^{14}$. Drakonaki et al. consider that owing to the lack of standardization and limited research, elastography in its current form remains a highly subjective technique, with debatable clinical value, but with proper standardization and further structured research, it may become a valuable supplementary tool in the investigation of musculoskeletal disease ${ }^{15}$. There are very little literature data on the use of elastography in testes, as well as on normal elastography values of testicular tissue.

Hattapoglu et al. in their study analyzed operated undescended testicles using shear wave elastography and found a statistically significant difference $(\mathrm{p}<0.001)$ in stiffness between scrotally placed testes and operated undescended testicles ${ }^{16}$. Kantarci et al. showed in their research that the areas of segmental

\section{Table 1. Mean EI values according to diagnosis}

\begin{tabular}{|l|l|}
\hline & Mean EI (L/R) \\
\hline Healthy subjects $(\mathrm{n}=40)$ & $1.34 / 1.49$ \\
Pathologic condition: & \\
Varicocele ( $\mathrm{n}=20)$ & 2.14 \\
Infertility $(\mathrm{n}=18)$ & 1.92 \\
$\begin{array}{l}\text { Solitary testis after orchidectomy of } \\
\text { the other testicle }(\mathrm{n}=25)\end{array}$ & 2.35 \\
$\begin{array}{l}\text { Testicular tumor }(\mathrm{n}=6) \\
\text { After orchidopexy of undescended } \\
\text { testicle }(\mathrm{n}=3)\end{array}$ & 3.80 \\
Congenitally smaller testicle $(\mathrm{n}=5)$ & 2.67 \\
\hline
\end{tabular}

$\mathrm{EI}(\mathrm{L} / \mathrm{R})=$ elasticity index (left/right) testicular infarction were less hard than healthy tissue using shear wave elastography ${ }^{1}$. Pedersen $e t$ al. in their research using shear wave elastography found that elastography values of testicles with testicular microlithiasis were in the same range as those with normal testicular tissue ${ }^{7}$. Sun et al. using shear wave elastography were able to quantify torsional testis elasticity and yield additional diagnostic data for clinic to identify testicular torsion ${ }^{8}$.

A 7-point grading scale was used, ranging from 0 to 6 , with 0 being soft tissue and 6 very hard tissue. There are several different scales for strain elastography, depending on the manufacturer and its software, while with shear wave elastography the results are expressed in $\mathrm{kP}$ or $\mathrm{m} / \mathrm{s}$. Trottmann et al. in their study measured the normal elasticity values of testicles using shear wave elastography and came to a conclusion that the values in the center of testicles were different than in its poles, and that the values were also dependent on the subject's age. The measured values were $1.15 \mathrm{~m} / \mathrm{s}$ in testicular poles and $0.90 \mathrm{~m} / \mathrm{s}$ in the center, and increased with age ${ }^{4}$. In the study by Hattapoglu et al., the measured values in normal subjects using shear wave elastography were in the range of $0.65-1$ (median $0.82) \mathrm{m} / \mathrm{s}^{16}$. Kantarci et al. measured a value of $2.6 \mathrm{kPa}$ for normal testcles using shear wave elastography ${ }^{1}$. In the available literature, to our knowledge, there are no studies that used a 7-step scale as in our research, and it is not possible to properly compare our measured reference values and other measured values with the values reported in other studies.

One of the goals of this prospective study was to determine if there is a difference in stiffness of testicular tissue between infertile patients and healthy subjects, and to determine whether patients diagnosed with infertility have stiffer testicular tissue, which we

Table 2. Comparison of elasticity index values in various pathologic conditions of testicles

\begin{tabular}{|l|l|l|l|l|l|l|}
\hline & & \multirow{2}{*}{} & $\mathrm{t}$ & \multirow{2}{*}{ Sig. (2- tailed) } & Mean difference & \multicolumn{2}{|l|}{$\begin{array}{l}\text { 95\% confidence interval } \\
\text { of difference }\end{array}$} \\
\cline { 5 - 8 } & & & & & Lower & Upper \\
\hline Varicocele & 2.756 & 19 & 0.013 & 0.56500 & 0.1360 & 0.9940 \\
Infertility & 2.919 & 35 & 0.006 & 0.34667 & 0.1056 & 0.5878 \\
Solitary testicle after orchidectomy & 3.710 & 24 & 0.001 & 0.77800 & 0.3452 & 10.2108 \\
Testicular tumor & 7.148 & 5 & 0.001 & 20.23000 & 10.4280 & 30.0320 \\
Orchidopexy & 3.774 & 2 & 0.064 & 10.09667 & -0.1537 & 20.3470 \\
Congenitally smaller testicle & 2.496 & 4 & 0.067 & 10.13000 & -0.1271 & 20.3871 \\
\hline
\end{tabular}


managed to prove statistically. Elevated mean EI values were found in patients with infertility with a mean EI value of $1.92 \pm 0.71$. Comparison of the mean EI values between healthy subjects and infertile patients yielded a statistically significant difference ( $\mathrm{p}=0.006)$.

We also found significantly increased levels of EI in testicular tumors $(3.80 \pm 0.70)$, which is understandable considering tumor structure and hypercellularity, as already described in a number of studies of other organs ${ }^{6,9-12,14,17}$, as well as in the existing studies on testicular elastography. Lock et al. found Leydig tumor tissue to be harder than normal testicular tissue ${ }^{3}$. In our study, we recorded elevated EI values in solitary testicle after orchidectomy of the other testicle. Although it is not clear why EI values are elevated in solitary testicle after orchidectomy of the other testicle, one theory is that it is a repercussion of therapy. Another theory is that the parenchyma of both testicles was initially harder, with higher elastography values. We point out that these theories are not mentioned in the literature, but a result of our own reasoning concerning this group of patients. In patients with varicocele of the left hemiscrotum, our explanation is that venous vascular changes in the scrotum indirectly elevate EI values of the left testicle, since elevated elastography values were found only in the left testicle, i.e. on the side where varicocele was present.

Dede et al. in their research using shear wave elastography found that infertile patients with varicocele had softer testicular tissue than infertile patients without variceocele ${ }^{5}$. Camoglio et al. used strain elastography and conclude that testicles were significantly stiffer in patients with varicocele, depending on the degree of varicocele ${ }^{18}$.

As for the congenitally smaller testicle or testicles after orchidopexy, we assume their stiffness is also increased, but in our research, we did not demonstrate a statistically significant difference even though the median value of the measured EI was elevated.

By using sonoelastography complementary to ultrasound examination of the testicles and scrotum, the sensitivity and specificity of the examination are increased, not only in distinguishing between benign and malignant lesions, but also in detecting tissue stiffness disorders that are not detectable by standard ultrasound examination. A limitation of this method is that it is a semi-quantitative method that is not completely as objective as a quantitative method such as shear wave elastography.
However, our study demonstrated difference in the measured elastography values between healthy subjects and those with a spectrum of different pathomorphological changes such as testicular tumors, scrotal varicocele, or following testicular operations (orchidectomy, orchidopexy). A statistically significant difference in EI values was also found between healthy subjects and infertile patients. In contrast to healthy patients whose EI values ranged from $1.34 \pm 0.35$ for the right testicle and $1.49 \pm 0.47$ for the left testicle, elevated EI values were recorded in patients with varicocele (EI $2.14 \pm 0.89$ ), infertility $(1.92 \pm 0.70)$, solitary testicle after orchidectomy of the other testicle $(2.35 \pm 1.03)$, testicular tumors $(3.80 \pm 0.70)$, after orchidopexy of undescended testicle $(2.67 \pm 0.41)$ and in congenitally smaller testicle $(2.70 \pm 0.91)$. The majority of these results were statistically significant and irrefutably confirmed the importance and usefulness of this method in conventional ultrasound examinations. In the future, with the required standardization of available technologies and methods of examination, and after defining reference values for every individual tissue and organ, elastography will become an important and irreplaceable complementary method to ultrasound examination, possibly the most important after the discovery of Doppler.

\section{References}

1. Kantarci F, Cebi Olgun D, Mihmanli I. Shear-wave elastography of segmental infarction of the testis. Korean J Radiol. 2012;13(6):820-2. doi: 10.3348/kjr.2012.13.6.820

2. Schurich M, Aigner F, Frauscher F, Pallwein L. The role of ultrasound in assessment of male fertility. Eur J Obstet Gynecol Reprod Biol. 2009;144 Suppl 1:S192-8. doi: 10.1016/j. ejogrb.2009.02.034

3. Lock G, Schröder C, Schmidt C, Anheuser P, Loening T, Dieckmann KP. Contrast-enhanced ultrasound and real-time elastography for the diagnosis of benign Leydig cell tumors of the testis - single center report on 13 cases. Ultraschall Med. 2014;35(6):534-9. doi: 10.1055/s-0034-1385038

4. Trottmann, Marcon J, D’Anastasi M, Bruce MF, Stief CG, Reiser MF, Buchner A, Clevert DA. Shear-wave elastography of the testis in the healthy man - determination of standard values. Clin Hemorheol Microcirc, 2016;62(3):273-81. doi: 10.3233/CH-162046

5. Dede O, Teke M, Daggulli M, Utangaç M, Baş O, Penbegül N. Elastography to assess the effect of varicocele on testes: a prospective controlled study. Andrology. 2016;48(3):257-61. doi: 10.1111/and.12440 
6. Aigner F, De Zordo T, Pallwein-Prettner L, Junker D, Schäfer G, Pichler R, Leonhartsberger N, Pinggera G, Dogra VS, Frauscher F. Real-time sonoelastography for the evaluation of testicular lesions. Radiology. 2012;263(2):584-9. doi: 10.1148/ radiol.12111732

7. Pedersen MR, Osther PJ, Rafaelsen SR. Testicular microlithiasis and preliminary experience of acoustic radiation force impulse imaging. Acta Radiol Open. 2016 Jul;5(7):205846011 6658686. doi: $10.1177 / 2058460116658686$

8. Sun Z, Xie M, Xiang F, Song Y, Yu CJ, Zhang Y, Ramdhany SK, Wang J. Utility of real-time shear wave elastography in the assessment of testicular torsion. PLoS One. 2015;10(9): E0138523. doi: 10.1371/journal.pone.0138523

9. Balleyguier C, Ciolovan L, Ammari S, Canale S, Sethom S, Al Rouhbane R, Vielh P, Dromain C. Breast elastography: the technical process and its applications. Diagn Interv Imaging. 2013;94(5):503-13. doi: 10.1016/j.diii.2013.02.006

10. Liu B, Zheng Y, Shan Q, Lu Y, Lin M, Tian W, Xie X. Elastography by acoustic radiation force impulse technology for differentiation of benign and malignant breast lesions: a metaanalysis. J Med. Ultrason. 2016;43(1):47-55. doi: 10.1007/ s10396-015-0658-9

11. Monpeyssen H, Tramalloni J, Poirée S, Hélénon O, Correas JM. Elastography of the thyroid. Diagn Interv Imaging. 2013;94(5):535-44. doi: 10.1016/j.diii.2013.01.023

12. Cantisani V, Lodise P, Grazhdani H, Mancuso E, Maggini E, Di Rocco G, D’Ambrosio F, Calliada F, Redler A, Ricci P, Cat- alano C. Ultrasound elastography in the evaluation of thyroid patology. Current status. Eur J Radiol. 2014;83(3):420-8. doi: 10.1016/j.ejrad.2013.05.008

13. Ferraioli G, Parekh P, Levitov AB, Filice C. Shear wave elastography for evaluation of liver fibrosis. J Ultrasound Med. 2014;33(2):197-203. doi: 10.7863/ultra.33.2.197

14. Boehm K, Salomon G, Beyer B, Schiffmann J, Simonis K, Graefen M, Budaeus L. Shear wave elastography for localization of prostate cancer lesions and assessment of elasticity thresholds: implications for targeted biopsies and active surveillance protocols.J Urol.2015;193(3):794-800. doi: 10.1016/j. juro.2014.09.100

15. Drakonaki EE, Allen GM, Wilson DJ. Ultrasound elastography for musculoskeletal applications. Br J Radiol. 2012;85 (1019):1435-45. doi: 10.1259/bjr/93042867

16. Hattapoğlu S, Göya C, Arslan S, Alan B, Ekici F, Tekbaş G, Yildı İ, Hamidi C. Evaluation of postoperative undescended testicles using point shear wave elastography in children. Ultrasonics. 2016;72:191-4. doi: 10.1016/j.jmu.2017.03.012

17. Barr RG. Elastography in clinical practice. Radiol Clin North Am. 2014;52(6):1145-62. doi: 10.1016/j.rcl.2014.07.002

18. Camoglio FS, Bruno C, Peretti M, Bianchi F, Bucci A, Scirè G, Patanè $\mathrm{S}$, Zampieri $\mathrm{N}$. The role of sonoelastography in evaluation of testes with varicocele. Urology. 2017;100:203-6. doi: 10.1016/j.urology.2016.08.005

\title{
Sažetak \\ ULOGA ULTRAZVUČNE ELASTOGRAFIJE U DIJAGNOSTICI PATOLOŠKIH STANJA TESTISA I SKROTUMA
}

\author{
M. Muršiç, I. Sjekavica, M. Šimunović i D. Ježek
}

Prije nekoliko godina pojavila se elastografija kao potencijalno vrlo korisna ultrazvučna metoda koja je danas u svakodnevnoj upotrebi u dijagnostici dojke, jetre i drugih organskih sustava, dok je za druge organe još u fazi istraživanja i evaluacije. Cilj istraživanja bio je usporediti indeks elastičnosti (EI) testisa u zdravih ispitanika i bolesnika s patološkim promjenama testisa i skrotuma. Istraživanje je provedeno kod ukupno 117 ispitanika od kojih je bilo 40 zdravih i 77 ispitanika s patološkim promjenama testisa i skrotuma. Mjerenja su provedena na ultrazvučnom aparatu Logiq E9 primjenom programa za sonoelastografska mjerenja. Kod zdravih ispitanika vrijednosti EI bile su $1,34 \pm 0,35$ za desni testis i $1,49 \pm 0,47$ za lijevi testis. Prema vrijednosti EI, pojačana tvrdoća tkiva testisa uočena je kod sljedećih stanja: varikokele, neplodnosti, ostatnog testisa kod stanja nakon orhidektomije drugog testisa, tumora testisa, stanja nakon orhidopeksije nespuštenog testisa i kongenitalno manjeg testisa. Malo je podataka u literaturi o elastografiji testisa, kao i o normalnim elastografskim vrijednostima tkiva testisa. Elastografija testisa se u našem ispitivanju pokazala korisnom metodom za dobivanje dodatnih dijagnostičkih informacija kod bolesnika s patološkim promjenama testisa i skrotuma, no potrebna su daljnja istraživanja s većim skupinama bolesnika.

Ključne riječi: Ultrazvučna elastografija; Testis; Skrotum; Varikokele; Neplodnost; Tumor testisa 